\title{
PENERAPAN METODE USABILITY PADA PERANCANGAN WEBSITE KANTOR KECAMATAN SINAR PENINJAUAN KABUPATEN OGAN KOMERING ULU
}

\author{
Wisnumurti \\ Program Studi Manajemen Informatika, AMIK AKMI Baturaja \\ Email: wisnumurti@akmi-baturaja.ac.id
}

\begin{abstract}
Abstrak
Dalam Perkembangan teknologi saat ini kehadiran komputer sebagai sarana komunikasi dalam masa sekarang ini banyak membawa perubahan, baik dalam dunia pendidikan, usaha, instansiinstansi pemerintah, maupun swasta, salah satunya adalah Website. Website merupakan salah satu aplikasi pada internet yang berupa informasi Hypertext, dimana Hypertext dapat membaca dan menelusuri informasi tersebut secara virtual tanpa terkait pada media tertentu. Melalui website dapat memasarkan produk atau jasa, mempromosikan suatu perusahaan, dan lain-lain. Dengan adanya aplikasi website yang dirancang dan dibangun di harapkan dapat membantu pengguna,penikmat internet tentu saja akan merasa nyaman dengan suatu situs jika mudah digunakan, memiliki tampilan yang menarik, dan mudah dipelajari. Dengan adanya pemikiran tersebut maka digunakan metode Usability pada Perancangan Website Kantor Kecamatan Sinar Peninjauan Kabupaten Ogan Komering Ulu dengan menggunakan metode waterfall sebagai metodologi perancangan system.
\end{abstract}

Kata kunci: Website, virtual Hypertext, Usability, waterfall

\begin{abstract}
In the current development of technology the presence of computers as a means of communication in the present has brought many changes, both in the world of education, business, government agencies, and private sector, one of which is the Website. The website is one of the applications on the internet in the form of Hypertext information, where Hypertext can read and trace that information virtually without being linked to certain media. Through the website can market products or services, promote a company, and others. With the website application designed and built it is hoped that it can help users, internet connoisseurs will naturally feel comfortable with a site if it is easy to use, has an attractive appearance, and is easy to learn. With these thoughts, the Usability method is used in the Design of Kantor Kecamatan Sinar Peninjauan Kabupaten Ogan Komering Ulu by using the waterfall method as a system design methodology.
\end{abstract}

Keywords - Website, virtual Hypertext, Usability, waterfall 


\section{PENDAHULUAN}

Pada Kemajuan teknologi komputer dalam segala bidang ilmu pengetahuan di kehidupan sehari-hari memegang peranan yang cukup besar. Komputer biasanya digunakan untuk menghasilkan atau membuat suatu informasi.

Internet merupakan media informasi yang sangat cepat dan efesien dalam penyebaran informasi dan tidak lepas dari jarak dan waktu, sehingga keberadaan media ini telah membentuk suatu budaya masyarakat yang baru, lainnya dunia cyber. Untuk mencari informasi di internet dapat dilakukan dengan mengunjungi situs (website) yang berhubungan dengan informasi yang dibutuhkan atau dapat dilakukan pencarian disitus pencarian.

Hampir setiap orang pernah menggunakan internet berupa website, dan ada banyak pula orang yang membuat website. Berdasarkan banyaknya pengguna Website, maka dengan ini sebaiknya kita menggembangkan sebuah website berdasarkan keinginan pengguna atau penggalaman pengembang website.

Dengan banyaknya website yang ada maka dalam mendesain sebuah web sangatlah penting untuk melihat pengalaman pengguna atau yang disebut User Experience. Dengan melihat dari User Experince dalam membuat situs web mudah digunakan efektif bagi pengunjung. Dalam perancangan website ada beberapa hal perlu dipertimbangkan seperti bagaimana membuat desain antarmuka (interface), dan kegunaan (usability) dalam suatu website yang mna kita bisa menilai seberapa jauh website bisa digunakan oleh pengguna agar mencapai tujuan yang diharapkan dengan kepuasan pengguna

Aplikasi website yang akan dibangun diharapkan dapat membantu pengguna, dan penikmat internet, dengan aplikasi ini diharapkan menimbulkan rasa nyaman dengan suatu situs jika mudah digunakan, memiliki tampilan yang menarik, dan mudah dipelajari. Dengan berdasarkan latar belakang ini dibuatlah penelitian dengan judul "Penerapan Metode Usability Pada Perancangan Website Kantor Kecamatan Sinar Peninjauan Kabupaten Ogan Komering Ulu".

Dalam perumusan masalah yang ada menjadi pokok permasalahan pada penelitian ini adalah bagaimana sistem ini dapat mempermudah pengguna dalam pemberian informasi dan pengambilan data melaui survey atau ujian. Rumusan permasalahannya yaitu aplikasi ini berbasis web, pada penelitian ini peneliti menggunakan Mozilla firefox, administrator dapat menginput, mengedit dan menghapus data semua halaman, sistem tidak membahas keamanan untuk menjaga data dan aplikasi yang akan dibuat adalah website Kantor Kecamatan Sinar Peninjauan Kabupaten Ogan Komering Ulu

Berdasarkan rumusan dan latar belakang di atas, maka tujuan yang ingin dicapai dari penelitian ini adalah untuk membuat aplikasi website berbasis usability untuk mempermudah pemberian dan pengumpulan informasi maupun data.

Bagi pihak pengguna yang pertama admin mempermudah memberikan informasi atau pengumpulan data melalui survey atau ujian, dan untuk pengguna lainnya lebih mudah mendapat informasi.

\section{TINJAUAN PUSTAKA}

\subsection{Pengertian Website}

Website adalah sebuah media yang berisi halaman-halaman yang berisikan informasi yang bisa diakses lewat jalur internet dan dapat dinikmati secara global (seluruh dunia). Sebuah website pada dasarnya adalah barisan kode-kode yang berisi kumpulan perintah, yang kemudian diterjemahkan melalui sebuah browser [1]

Website adalah kumpulan dari halaman-halaman situs yang terangkum 
dalam sebuah domain atau subdomain, yang tempatnya berada dalam World Wide web (WWW) di dalam internet. Sebuah halaman web biasanya berupa dokumen yang ditulis dalam format HTML (Hyper Text Markup Languange), yang selalu bisa diakses melalui HTTP yaitu sebuah protocol yang menyampaikan informasi dari server website untuk ditampilkan kepada para pemakai melalui web browser [2].

Website adalah rangkaian atau sejumlah halaman di internet yang memiliki topik saling terkait untuk mempresentasikan suatu informasi. Website juga merupakan miniatur dan representasi dari perorangan, lembaga, organisasi, ataupun perusahaan yang bersangkutan. Website memberikan informasi, gambaran, serta visualisasi orang/lembaga yang membuatnya [3].

Website dapat dibuat dengan tujuan berbagai macam, sesuai dengan keperluan pemiliknya. Contoh website yang sering dijumpai adalah sebagai berikut [3]:

a. Website untuk mencari informasi (search engine), misalnya: google.com yahoo.com, dll.

b. Website jejaring sosial (social media), misalnya facebook.com, twitter.com, dll.

c. Website took online (online shop), misalnya: blibli.com, lazada.co.id,dll.

d. Website perusahaan (company profile), misalnya: pertamina.com, pln.co.id, dll.

e. Website partai berita (news), misalnya: detik.com, kapanlagi.com, dll.

f. Website perorangan (personal rate), misalnya: iffahmedia.com, dll.

Untuk membuat website banyak sekali software yang dapat digunakan, diantaranya sebagai berikut: HTML, PHP, Dream Weaver, dan CMS.
1 Jenis-jenis website

Secara garis besar, website dapat dikelompokkan menjadi 3 macam yaitu sebagai berikut: [2]

\section{a. Website Statis}

Website stastis adalah website yang memiliki halaman tidak berubah. Yang artinya yaitu untuk melakukan perubahan pada suatu halaman dilakukan secara manual dengan mengedit kode yang menjadi struktur dari website tersebut.

\section{b. Website Dinamis}

Website dinamis adalah website yang secara struktur ditujukan untuk update sesering mungkin. Biasanya selain utama yang dapat diakses oleh user pada umumnya, juga disediakan halaman backend untuk mengedit konten dari website. Contoh umum tentang website dinamis adalah website berita atau website portal yang didalamnya terdapat fasilitas berita, polling dan lain sebagainya.

\section{c. Website Interaktif}

Website interaktif adalah website yang saat ini sedang terkenal dan sering digunakan. Salah satu contoh website interaktif adalah blog dan forum. Dalam website ini user dapat berinteraksi dan beradu pendapat tentang apa yang menjadi pemikiran mereka. Pada umunya website ini memiliki moderator untuk mengatur agar topik yang diperbincangkan atau didiskusikan tidak keluar jalur.

\section{Pengertian Aplikasi Berbasis Website}

Berbasis web merupakan sebuah aplikasi yang menggunakan teknologi browser untuk menjalankan aplikasi dan diakses melalui jaringan komputer. Aplikasi berbasis website adalah sebuah aplikasi yang dapat diakses melalui internet dan pada zaman sekarang ini ternyata lebih luas pemakaiannya. Banyak dari perusahaanperusahaan berkembang yang menggunakan Aplikasi Berbasis Web dalam merencanakan 
sumber daya mereka dan untuk mengelola perusahaan mereka [4].

Aplikasi berbasis web digunakan untuk berbagai macam tujuan yang berbeda. Sebagai contoh, aplikasi berbasis web bisa digunakan untuk membuat invoice dan memberikan cara yang mudah dalam penyimpanan data di database. Aplikasi ini juga dapat digunakan untuk mengatur persediaan karena fitur tersebut sangat berguna. Bukan hanya itu saja aplikasi berbasis web juga dapat bekerja memonitoring dalam sistem hal tampilan [4].

Dari pengertian diatas dapat disimpulkan aplikasi web merupakan aplikasi yang diakses menggunakan web browser melalui jaringan internet atau intranet. Aplikasi web juga merupakan suatu perangkat lunak komputer yang dikodekan dalam bahasa pemrograman yang mendukung perangkat lunak berbasis web seperti HTML, JavaScript, CSS, Ruby, Python, PHP, Java dan bahasa pemrograman lainnya.

\subsection{Pengertian Sistem Informasi}

Dalam mempelajari sistem kita harus mempelajari informasi, pasalnya suatu sistem yang kurang mendapatkan suatu informasi akan menjadi ketinggalan zaman/tidak bertahan lama. Informasi dapat berupa data mentah, data tersusun dan sebagainya, dimana data adalah suatu kenyataan yang bermanfaat menggambarkan suatu kejadian-kejadian dan kesatuan yang nyata. Gagasan penting yang mendasari pemakaian istilah informasi dalam sistem informasi adalah memperkaya penyajian, mempunyai nilai kejutan atau mengungkapkan sesuatu. Informasi dapat merubah kemungkinan-kemungkinan hasil yang diharapkan dalam sebuah situasi keputusan.

Karena itu Informasi mempunyai nilai dalam proses keputusan. Informasi adalah
:Data yang diolah menjadi bentuk yang lebih berguna dan berarti bagi penerimanya [5]. Informasi secara umum dalam pemakaian sistem informasi adalah Data yang telah diolah menjadi sebuah bentuk yang berarti dan berguna bagi penerimanya untuk mengambil keputusan masa kini maupun yang akan datang.[6]

Sedangkan Informasi adalah data yang telah diolah menjadi bentuk yang lebih berarti bagi penerimanya [6]. Jadi dapat disimpulkan bahwa Informasi adalah data yang dirubah/diproses menjadi bentuk yang lebih berguna dan berarti dalam pengambilan keputusan.

Sistem yaitu sekelompok yang menekankan pada prosedur dan kelompok yang menekankan pada elemen atau komponenya pendekatan yang menekankan pada prosedur mendefinisikan sistem sebagai suatu jaringan kerja dari prosedur prosedur yang saling berhubungan, berkumpul bersama-sama untuk melakukan suatu kegiatan atau menyelesaikan suatu sasaran tertentu [7].

Model umum sebuah sistem terdiri dari input, proses dan output, hal ini merupakan konsep sebuah sistem yang sangat sederhana mengingat sebuah sistem dapat mempunyai beberapa pemasukkan dan pengeluaran sekaligus [7]. Selain itu sebuah sistem juga memiliki karakteristik atau sifatsifat tertentu, yang mencirikan bahwa hal tersebut bisa dikatakan sebagai suatu sistem.

Adapun karakteristik yang dimaksud adalah sebagai berikut:

1. Komponen sistem (components)

Suatu sistem yang terdiri dari sejumlah komponen yang saling berinteraksi, yang berkerjasama membentuk satu kesatuan.

2. Batasan sistem sistem (Boundary)

Ruang lingkup sistem merupakan daerah yang membatasi antara sistem dengan sistem lainya atau sstem dengan lingkungan luarnya.

3. Lingkungan Luar sistem (Environtment) 
Bentuk apapun yang ada di luar lingkup atau batasan sistem yang mempergaruhi operasi sistem tersebut disebut dengan lingkungan luar dari sistem

4. Penghubung sistem (Interface)

Sebagai media yang menghubungkan sistem dengan sub sistem yang lainnya.

5. Masukkan sistem (input)

Energi yang dimasukkan kedalam sistem disebut masukkan sistem, yang berupa pemeliharaan (maintenance input) dan sinyal (signal input).

6. Keluaran sistem (output)

Hasil dari energy yang diolah dan di klarifikasikan menjadi keluaran yang berguna.

7. Pengolahan sistem (proses)

Suatu sistem dapat mempunyai suatu proses yang akan mengubah masukkan menjadi pengeluaran.

8. Sasaran sistem (objective)

Suatu sistem memiliki tujuan dan sasaran yang pasti dan sifat deterministik.

Sistem Informasi adalah data yang telah diolah untuk digunakan untuk mengambil keputusan [7]. Sistem pengolahan informasi akan mengelolah data menjadi informasi atau pengolah data dari bentuk tak berguna menjadi berguna bagi penerimanya. nilai informasi berhubungan dengan keputusan. bila tidak ada pilihan atau keputusan maka informasi tidak diperlukan keputusan dapat berkisar dari keputusan maka informasi tidak diperlukan.

Teori informasi lebih tepat disebut sebagai teori matematika komunikasi yang memberikan pandangan yang berguna bagi sistem informasi, yang mana konsep informasi menunjukkan hubungan interval informasi, sumber dari informasi adalah data.

\subsection{Kualitas Informasi}

Informasi yang memiliki kualitas baik akan menentukan efektifitas dalam pengambilan keputusan pada suatu organisasi. John Burch dan Gary Grudnitski menyebutkan adanya tiga pilar utama yang menentukan kualitas dari suatu informasi yaitu : Akurat, Tepat pada waktunya dan Relevan. Informasi yang menjelaskan dengan rinci dan lengkap tentang syaratsyarat Informasi yang dikatakan berkualitas yaitu apabila mempunyai karakteristikkarakteristik[7] sebagai berikut:

1. Akurat

2. Relevan

3. Tepat Waktu

4. Ekonomis

5. Efisien

6. Dapat Dipercaya

\subsection{Metode Usability}

Usability pada dasarnya berguna atau dapat digunakan. Jadi, Usability dalam kaitan dengan IMK merupakan suatu sistem yang dapat bekerja dengan baik apabila dipergunakan secara maksimal oleh pengguna, sehingga semua kemampuan sistem dapat dapat bermanfaat secara maksimal. Usability memiliki lima komponen yaitu :

1. Learnability: Seberapa mudah bagi pengguna memahami saat pertama kali melihat.

2. Efficiency : Seberapa cepat dapat menyelesaikan perintah (input).

3. Memorability :Saat pengguna menggunakan lagi seberapa ingat (terbisa) terhadap penggunaanya.

4. Errors : Berapa banyak kesalahan yang diperbuat saat menggunakannya.

5. Satisfaction: Seberapa nyaman pengguna dengan antarmuka tersebut.

Sedangkan tujuan dari usability pada dasarnya efektif, efisien, aman pada penggunaannya, mudah untuk 
dipelajari/dipahami, diingat, serta memiliki utilitas yang baik.

\subsection{Analisis Keunggulan Usability}

Bertujuan untuk membuat evaluasi Seberapa mudah bagi pengguna memahami saat pertama kali melihat (Learnability), Seberapa cepat dapat menyelesaikan perintah dalam penginputan (Efficiency), Saat pengguna menggunakan lagi seberapa ingat (terbisa) terhadap penggunaanya (Memorability), Berapa banyak kesalahan yang diperbuat saat menggunakannya (Errors ) dan Seberapa nyaman pengguna dengan antarmuka tersebut (Satisfaction).

Adapun keunggulan suatu Website Kecamatan dengan menggunakan analisis Usability adalah sebagai berikut :

a. pengguna menjadi lebih memahami kekuatannya dan memberikan rekomendasi untuk meningkatkannya.

b. pengguna dapat melihat situasi Seberapa cepat dapat menyelesaikan perintah dalam penginputan.

c. Pengguna mengetahui Seberapa cepat dapat menyelesaikan perintah dalam penginputan

d. Pengguna juga dapat mengetahui berapa banyak kesalahan yang diperbuat saat menggunakannya

e. Pengguna dapat merasakan Seberapa nyaman pengguna dengan antarmuka tersebut.

\subsection{Analisis Kebutuhan Sistem dan Usability}

Analisis kebutuhan digunakan untuk mengidentifikasi kebutuhan dan kegunaan dari system yang akan di bangun. Kebutuhan system meliputi kebutuhan user dan kebutuhan admin. Kebutuhan system meliputi kebutuhan admin yaitu admin dapat dengan mudah memberikan informasi dan mengumpulkan data- data melalui survey dan ujian.

\subsection{Komponen Sistem Informasi}

Sistem informasi berbasis komputer (CBIS) dalam suatu organisasi terdiri dari komponen-komponen [8] berikut :

1. Perangkat Keras (Hardware)

Mencakup berbagai peranti fisik seperti komputer dan printer.

2. Perangkat Lunak (Software)

Program atau instruksi yang memungkinkan perangkat keras memproses data.

3. Basis Data (Database)

Kumpulan data dan informasi yang diorganisasikan sedemikian rupa sehingga cepat dan mudah diakses oleh pengguna sistem informasi.

4. Prosedur (Procedure)

Sekumpulan aturan yang meliputi strategi, kebijakan, metode dan peraturan-peraturan dalam menggunakan sistem informasi berbasis komputer.

5. Telekomunikasi

Komunikasi yang menghubungkan antara pengguna sistem dengan sistem komputer secara bersama-sama kedalam suatu jaringan kerja yang efektif.

6. Orang (Manusia)

Semua pihak yang bertanggung jawab dalam pengembangan sistem informasi, pemrosesan dan penggunaan keluaran sistem informasi.

\section{METODOLOGI PENELITIAN}

\subsection{Metodologi Pengembagan System}

Dalam melakukan pengembangan sistem sangat diperlukan suatu metodologi dalam mendefinisikan pendekatanpendekatan pengembangan. Tercapainya sasaran dari pengembangan sistem dipengaruhi oleh pendekatan dan metodologi yang digunakan dalam perencanaan dan perancangan sistem.

Metodologi merupakan pedoman bagaimana dan apa yang harus dikerjakan dalam mengembangkan sistem. Metodologi yang digunakan dalam pengembangan 
sistem Website adalah metodologi waterfall. Model waterfall kadang dinamakan siklus hidup klasik (classic life cycle), dimana hal ini menyiratkan pendekatan yang sistematis dan berurutan pada pengembangan perangkat lunak yang dimulai dengan spesifikasi kebutuhan pengguna dan berlanjut melalui tahapan-tahapan perencanaan (planning), pemodelan (modeling), konstruksi (construction), serta penyerahan sistem/perangkat lunak kepada para pelanggan/pengguna (deployment), yang diakhiri dengan dukungan berkelanjutan pada perangkat lunak. Waterfall adalah suatu teknik pengembangan sistem untuk merencanakan, memutuskan dan mengontrol proses pengembangan sistem informasi.

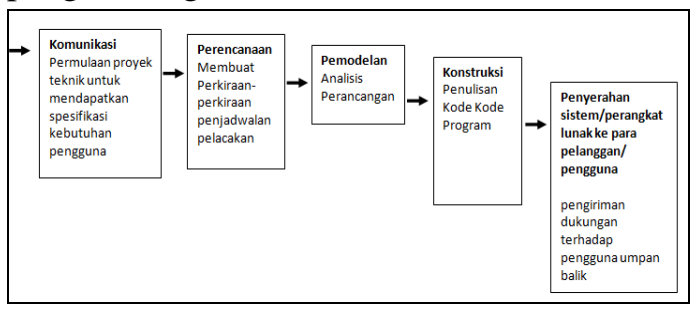

Gambar 1. Model Water fall

\subsection{Analisis Sistem}

Analisis sistem dapat diartikan sebagai Penguraian dari sistem informasi yang utuh kedalam bagian komponen dengan maksud untuk mengidentifikasi dan mengevaluasi permasalahan, kesempatan, hambatan yang terjadi dan kebutuhan yang diharapkan sehingga dapat diusulkan perbaikan-perbaikan.

Tahap analisis data sistem dilakukan setelah tahap perencanaan sistem dan sebelum tahap desain sistem.

Tahap analisa merupakan tahap yang sangat penting karena kesalahan dalam tahap ini menyebabkan kesalahan pada tahap selanjutnya. Selanjutnya langkahlangkah dasar yang harus ditempuh dalam tahap analisis adalah :
1. Identify, yaitu mengidentifikasi masalah.

2. Understand, yaitu memahami kerja dari sistem yang ada.

3. Analyze, yaitu menganalisa sistem.

4. Report, yaitu membuat laporan.

\subsection{Identifikasi Masalah Dan Penyebab Masalah}

Mengidentifikasi Masalah merupakan langkah pertama yang dilakukan dalam analisis sistem. Masalah dapat didefinisikan sebagai suatu hal yang ingin dipecahkan.Masalah inilah yang menyebabkan sasaran sistem tidak dapat dicapai.Oleh karena itu tahap pertama yang harus dilakukan pada tahap analisis sistem adalah mengidentifikasi terlebih dahulu masalah masalah yang terjadi.

Untuk mengidentifikasi masalah tersebut dapat dilakukan dengan mengkaji terlebih dahulu subyek-subyek yang telah diuraikan oleh manajemen atau yang telah ditemukan oleh analis sistem di tahap perencanaan sistem. Untuk kasus ini masalah- masalah yang terjadi adalah sebagai berikut :

1. Pengendalian terhadap data jadwal pelajaran yang kurang terkontrol dengan baik karena mengelola data guru, data kelas, data pengampu, data waktu, data pelajaran, yang kadang ada jadwal pelajaran yang sering double dan tidak terinputkan.

2. Data mata pelajaran dalam bentuk arsip dari tahun ketahun banyak yang hilang sehingga mencari data jadwal pengampu yang dibutuhkanpun mengalami kesulitan.

3. Pencatatan data mengelola data guru, data kelas, data pengampu, data waktu, data pelajaran dilakukan melalui Microsoft Excel sehingga menyita waktu ketika akan dilakukan pengecekan data kembali maupun pencarian data. 
4. Proses pembuatan laporan penjadwalan membutuhkan waktu yang lama.

Dari permasalahan permasalahan tersebut diatas dapat diidentifikasi bahwa penyebab utama masalah yang terjadi adalah karena pengolahan datanya masih dilakukan secara manual yaitu dengan mengandalkan kertas untuk pengarsipan data. Selain itu juga belum tersedianya program aplikasi yang dapat membantu untuk mengolah dan menganalisis laporan.

\subsection{Analisis Kelayakan Sistem}

Dalam pengerjaan Sistem baru yang ditawarkan harus diuji kelayakannya terlebih dahulu, apakah sistem tersebut lebih baik dari yang sudah ada atau malah sebaliknya. Sebelum spesifikasi-spesifikasi kebutuhan pengguna dapat dianalisis, dimodelkan, atau dispesifikasikan, mereka harus diperoleh melalui aktivitas-aktivitas komunikasi yang baik. Dalam hal ini, peneliti berkomunikasi dengan pengguna web yaitu mahasiswa, bahwa mereka memperoleh informasi- informasi tentang beberapa kecamatan terpisah- pisah ada baiknya semua informasi dan data- data dapat diperoleh tidak hanya dalam satu web saja.

\section{HASIL DAN PEMBAHASAN \\ 4.1 Hasil}

Hasil yang didapat dari penelitian ini adalah sebuah website Kecamatan Sinar Peninjauan, OKU Selatan yang dibuat menggunakan PHP \& MYSQL. pada Website ini terdiri dari beberapa halaman Web yang saling berhubungan antara satu dengan yang lainnya. Adapun hasil yang didapat dari website tersebut dengan tampilan halaman beranda seperti gambar gambar dibawah ini :
1 Halaman Home

Merupakan link ke halaman index. Pada saat pertama kali pengunjung mengakses website Kecamatan Sinar Peninjauan, Oku Selatan ini, maka halaman web yang akan ditampilkan adalah halaman index yang merupakan halaman utama berisi sambutan kepala Camat, Kecamatan Sinar Peninjauan. Pada halaman index terdapat link menu dan navigasi untuk menuju ke halaman lain dalam sebuah website. Berikut ini adalah halaman utama (index) dari situs web Kecamatan Sinar Peninjauan.

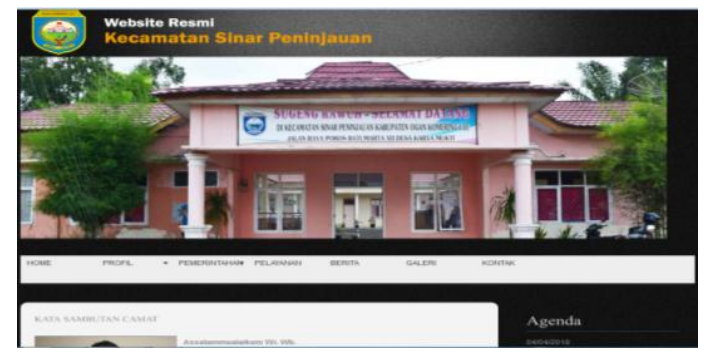

Gambar 2. Halaman Home

\section{Halaman Sejarah}

Berdirinya kecamatan sinar peninjauan adalah merupakan kebijakan pemerintah kabupaten ogan komering ulu dalam upaya mewujudkan pelayanan yang optimal kepada masyarakat.

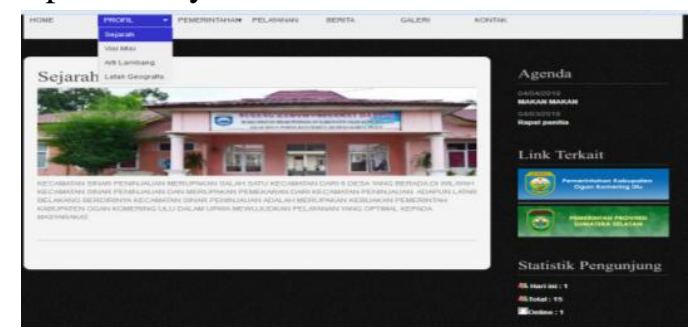

Gambar 3. Halaman Sejarah

\section{Halaman Visi dan Misi}

Merupakan link halaman yang membahas tentang visi dan misi Kecamatan Sinar Peninjauan. Berikut tampilan halaman visi dan misi Kecamatan Sinar Peninjauan. 


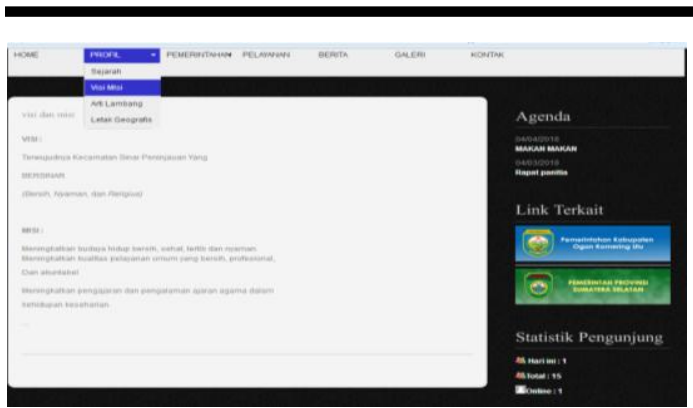

Gambar 4. Halaman Visi dan Misi

\section{$4 \quad$ Halaman Arti Lambang}

Kabupaten Ogan Komering Ulu atau yang disingkat Kabupaten OKU adalah satu dari tuju belas Kabupaten atau Kota yang berada dalam wilayah administrasi provinsi Sumatera Selatan.

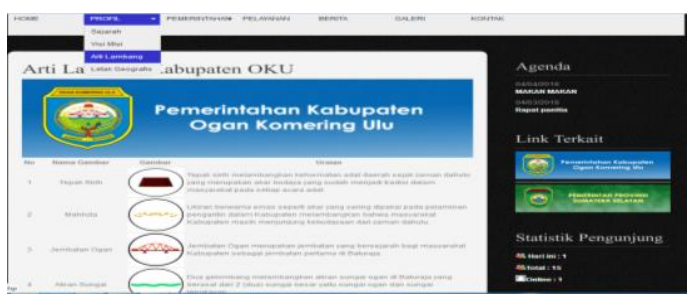

Gambar 5. Halaman Arti Lambang

\section{Halaman Letak Geografis}

Merupakan link halaman yang membahas tentang Wilayah Kecamatan Sinar Peninjauan. Berikut tampilan halaman Wilayah Kecamatan Sinar Peninjauan.

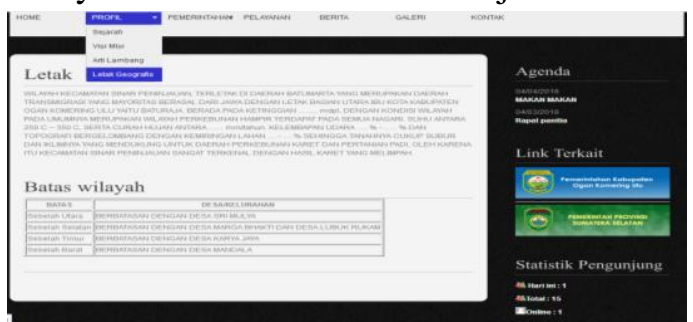

Gambar 6. Halaman Geografis

6 Halaman Potensi Daerah

Suatu bentuk sumber daya atau kemampuan yang cukup besar namun kemampuan tersebut belum tersingkap dan belum diaktifkan. Berikut tampilan halaman Potensi Daerah.

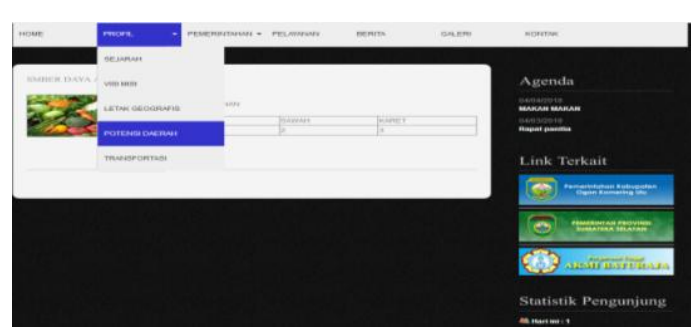

Gambar 7. Halaman Potensi Daerah

7 Halaman Transportasi

Transportasi yang digunakan oleh pihak Kecamatan Sinar Peninjauan. Berikut halaman Transportasi.

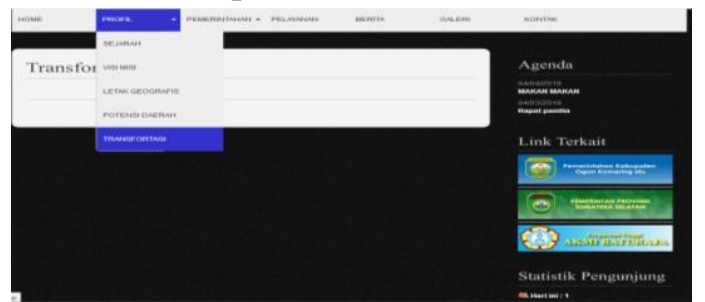

Gambar 8. Halaman Transportasi

8 Halaman Kepegawaian

Kepala sub bagian mempunyai tugas memimpin dan melaksanakan penyiapan bahan, menghimpun mengelolah dan melaksanakan administrasi, urusan ketatausahaan, meliputi pengelolaan urusan rumah tangga, surat menyurat, kearsipan, protocol, perjalanan dinas, perlengkapan, pengelolaan kepegawaian dan tugas umum lainnya. Berikut tampilan halaman Kepegawaian

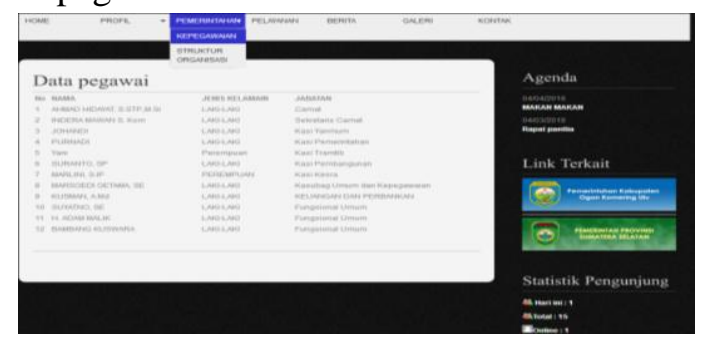

Gambar 9. Halaman Kepegawaian

9 Halaman Struktur Organisasi

Dalam Organisasi Kecamatan juga memiliki gambar struktur mengenai bagianbagian Kecamatan yang bisa dilihat gambar struktur agar mudah untuk diingat. Berikut tampilan halaman Struktur Organisasi. 


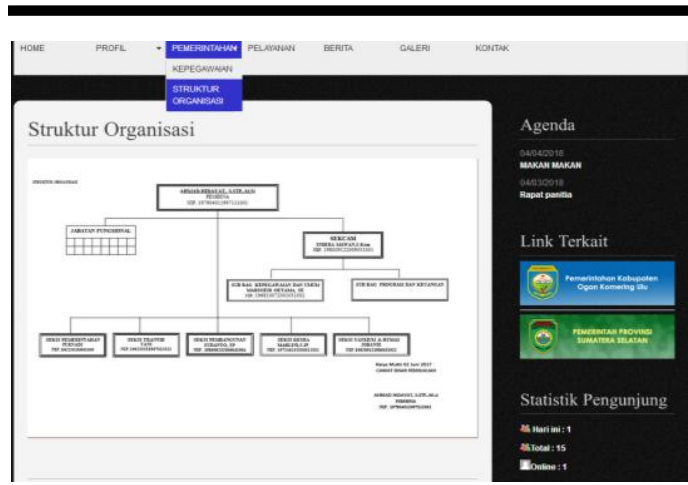

Gambar 10. Halaman Struktur Organisasi

10 Halaman Pelayanan

Pelayanan tersebut diberikan untuk memenuhi hak masyarakat, baik itu merupakan layanan civil maupun layanan public. Berikut tampilan halaman Pelayanan.

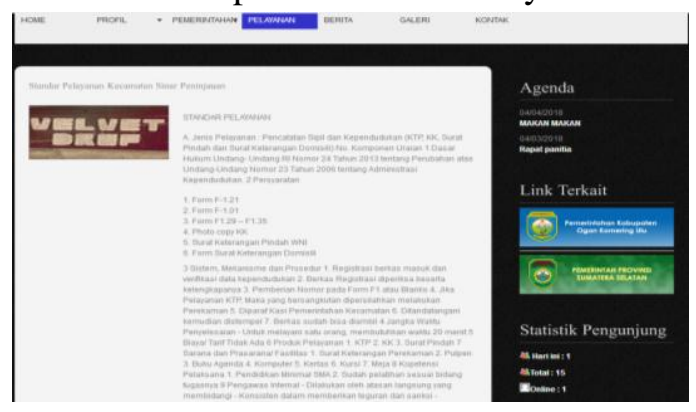

Gambar 11. Halaman Pelayanan

\section{Berita}

Berita informasi baru atau informasi mengenai sesuatu yang sedang terjadi diwilayah Kecamatan Sinar Peninjauan. Berikut tampilan halaman Berita.

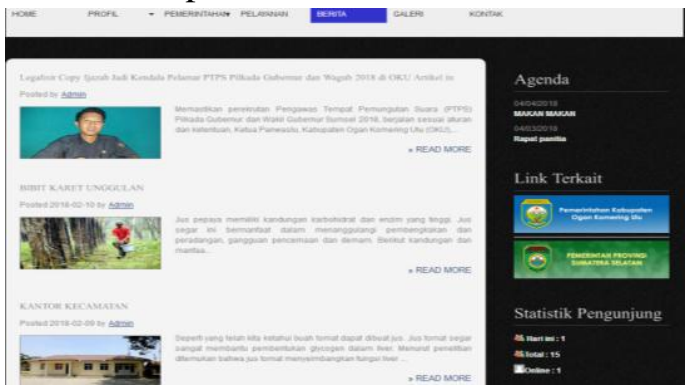

Gambar 12. Halaman Berita

12 Halaman Kontak

Merupakan link halaman yang membahas Kontak Kecamatan Sinar Peninjauan. Berikut tampilan halaman Kontak Kecamatan Sinar Peninjauan.

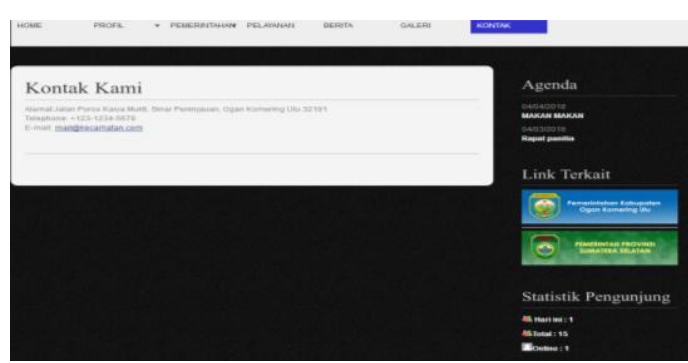

Gambar 13. Halaman Kontak

13 Halaman Admin

Merupakan link halaman yang membahas Admin Kecamatan Sinar Peninjauan. Berikut tampilan halaman Admin Kecamatan Sinar Peninjauan.

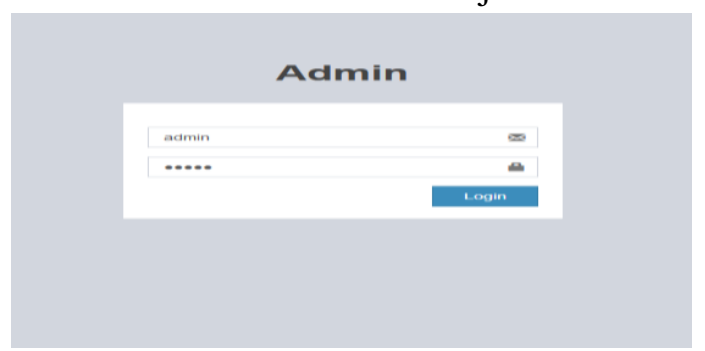

Gambar 14. Halaman Admin

14 Tampilan Administrator Admin

Merupakan link halaman yang membahas Administrator Admin Kecamatan Sinar Peninjauan. Berikut tampilan halaman Administrator Admin Kecamatan Sinar Peninjauan.

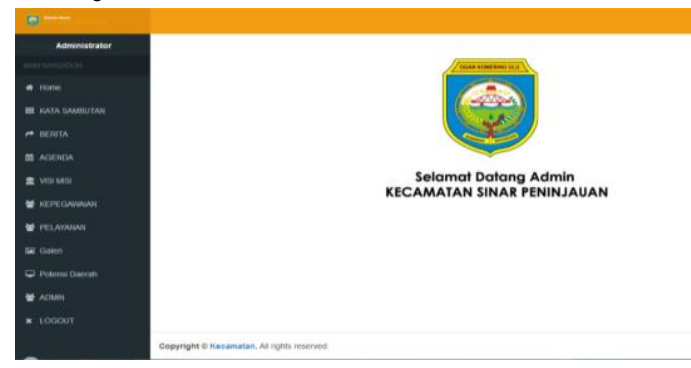

Gambar 15. Halaman Administrator Admin

\subsection{Implementasi Sistem}

Implementasi sistem (system implementation) adalah tahap untuk meletakkan suatu sistem supaya siap untuk dioperasikan. Tahap implementasi sistem meliputi rencana implementasi yang merupakan awal ditahap implementasi yang bertujuan untuk mengatur biaya dan waktu yang dibutuhkan selama tahap implementasi 
sistem. Selanjutnya pada tahapan ini adalah melakukan kegiatan yang mendukung dalam pembuatan sistem yang telah dirancang sebelumnya. Adapun rencana kegiatan yang dilakukan dalam tahap implementasi sistem adalah sebagai berikut :

1 Pengujian Program

2 Pengujian Sistem

3 Manual Program

4 Manual Instalasi

5 Pemilihan Dan Pelatihan Personil

6 Konversi Sistem

7 Pemeliharaan Sistem

8 Tindak Lanjut Implementasi

\section{KESIMPULAN}

Setelah menyelesaikan Implementasi Metode Usability ini, maka dapat disimpulkan sebagai berikut:

1. Dihasilkan suatu Website Kecamatan Sinar Peninjauan menggunakan metode Water Fall, untuk mempermudah memberikan informasi atau pengumpulan data melalui survey atau ujian.

2. Dan untuk pengguna lainnya yaitu user lebih mudah mendapat informasi.

3. Dengan adanya Website ini dapat membantu admin maupun user dalam proses pemberian informasi maupun mendapatkan informasi dari Kecamatan Sinar Peninjauan

\section{SARAN}

Adapun beberapa saran yang ingin penulis sampaikan adalah sebagai berikut:

1. Menyadari bahwa Website ini masih banyak kekurangannya, Website ini bisa dikembangkan lagi dengan fiturfitur yang lebih bermanfaat.

2. Apabila nantinya ada yang ingin pengembangan aplikasi ini, maka aplikasi ini bisa dibuat dengan menarik lagi dan dengan adanya fitur pelengkap yang bisa mempermudah dalam pemberian informasi dan pengumpulan data.

\section{DAFTAR PUSTAKA}

[1] Sarwono, J. (2015). Bikin Website Itu Mudah. Jakarta: Mediakita

[2] Wibowo, W. T. \& Purwanto, A., (2015). Analisis Perancangan Company Profile Berbasis Web Sebagai Sarana Promosi pada CV. OAK Merch Yogyakarta. STMIK AMIKOM, Yogyakarta Anhar, (2016). Panduan Bijak Belajar Internet Untuk Anak. Sukabumi: Adamssein Media.

[3] Ginanjar, T. (2014). Rahasia Membangun Website Toko Online Berpenghasilan Jutaan Rupiah. Bandung: Iffahmedia.

[4] Enjelina, S. \& Insannudin, E., (2016). Perancangan Aplikasi Berbasis Web Interaktif Haloapp Berbasis Android dan IOS. p. 2.

[5] Jogiyanto, 2009, Sistem Teknologi Informasi, Yogyakarta:CV ANDI OFFSET

[6] Ladjamudin, Al-Bahra Bin. 2005. Analisis dan Desain Sistem Informasi, Yogyakarta: Graha Ilmu.

[7] Sutabri Tata, 2012. Analisis Sistem Informasi. Andi. Yogyakarta.

[8] Stair, R.M., (1992), Quantitave Analysis For Management ( 8 th) . New York 